\title{
The community involvement of courts: an action research study in the context of the Polish justice system
}

\section{Przemysław Banasik, Sylwia Morawska and Agata Austen}

\begin{abstract}
Purpose - As a rule, common courts are hermetic organizations, separated from their stakeholders by procedures based on legal provisions. For these reasons, they are often perceived as unreliable and non-transparent, and as such, they do not inspire trust among stakeholders. The authors posit that the court's community involvement may lead to the increased accountability and legitimacy of courts, which should in turn result in jurisprudence benefits. This paper discusses the concept of community involvement of courts, demonstrates how this idea may be implemented and explains its benefits for courts.
\end{abstract}

Design/methodology/approach - The results of an action research study undertaken between June 2013 and March 2018 at the Regional Court in Gdansk (Poland) are discussed.

Findings - The results highlight factors underlying the implementation of the idea of community involvement, as well as the areas in which courts take these actions, and explain how it influences their accountability and legitimacy. This research describes the interests of different stakeholders and proposes a range of actions that may be taken by courts while cooperating with stakeholders to achieve the aims of community involvement. It also proposes a set of steps that enable courts to implement the idea of community involvement.

Originality/value - This paper develops the idea of the community involvement of courts, which may be used as an operating rule for public institutions to increase their legitimacy and accountability and explain its introduction in the context of courts. It offers a universal framework for the community involvement of courts that can be used in the context of any court in both the continental and Anglo-Saxon systems.

Keywords Stakeholders, Action research, Community involvement, Courts, Justice system, Social responsibility of public organizations

Paper type Research paper

\section{Introduction}

Justice is necessary to achieve both ethical and social balance in every community and to drive a healthy economy. Despite this crucial role, the justice system in many European countries, especially those in Eastern and Southern European countries, has an insufficiently trustworthy public image (Jackson et al., 2011). Courts are expected to make decisions in cases and matters efficiently and to a high standard while completing proceedings within a short period, as well as keeping the running costs at a reasonable level (Voigt, 2016). The rule of getting "value for money" has dominated other values of jurisprudence. Qualitative aspects such as the involvement of courts in pro-social actions remain an undervalued aspect of court activities.

Public sector institutions, similarly to private sector ones, need to meet the expectations of multiple stakeholders. Nowadays citizens expect ethical responsibility from public managers and organizations, and this increasing interest in social and ethical issues has produced a growing demand for greater accountability and transparency of public
Przemysław Banasik, Associate Professor is Judge at the Appeal Court in Gdańsk, Gdańsk, Poland. Sylwia Morawska is Associate Professor at the Department of Administrative and Financial Corporate Law, Warsaw School of Economics, Collegium of Business Administration, Warsaw, Poland. Agata Austen is Associate Professor at the Department of Human Resource Management, University of Economics in Katowice, Katowice, Poland.

Received 11 September 2020 Revised 12 January 2021 16 May 2021

Accepted 1 June 2021

(C) Przemysław Banasik Sylwia Morawska and Agata Austen. Published by Emerald Publishing Limited. This article is published under the Creative Commons Attribution (CC BY 4.0) licence. Anyone may reproduce, distribute, translate and create derivative works of this article (for both commercial and non-commercial purposes), subject to full attribution to the original publication and authors. The full terms of this licence may be seen at http://creativecommons.org/ licences/by/4.0/legalcode 
institutions (Ricci and Fusco, 2016). Also the justice system should operate in a transparent, credible and responsible way (Ricci and Fusco, 2016). Demand for a new paradigm, based on social responsibility, involves not only companies but also politics, public administrations and their relationship with stakeholders and society as a whole. Taking a multi-stakeholder perspective into consideration, social responsibility is an antecedent of organizational reputation which influences the behavior of stakeholders (Maden et al., 2012). For this reason, interest in research that investigates the perceptions of external stakeholders concerning the social responsibility of public sector organizations is growing. Social responsibility, which was originally linked to private sector stakeholders (Crowther and Seifi, 2020), is nowadays considered applicable to all types of organizations, including public sector organizations (Abdelmotaleb and Saha, 2018; Ates and Büttgen, 2011). We believe that the implementation of the idea of social responsibility and a component known as corporate community involvement in common courts may contribute to their opening up to the needs of stakeholders and establishing relations with them, which in turn may result in an improvement in the image of courts and, most importantly, improve the quality of the functioning of courts.

Thus, respecting the 'trias politica' framework, we posit that courts are institutions that should adopt some practices that have been introduced by private and other public institutions and gain a great deal by building relationships with stakeholders through engaging in pro-social actions. So far, community involvement is not common practice, although in some countries this idea is being applied. Examples can be found in Sweden (Contini, 2010) or the USA (Seattle Municipal Court, 2020). We posit that, apart from their core (judicial) activity, courts may play an active role in increasing the state of knowledge both of their functioning (structure, service processes) and in spreading knowledge of the law and social values based on equality and justice. In turn, it would recover trust in courts and create their positive reputation and image. Increasing legal awareness through listening to the expectations of the court's stakeholders and the court's involvement in the legal education of the local community may translate into the quality of jurisprudence. Therefore, it becomes necessary to open the courts and establish a dialogue with stakeholders by building a community-involved court which takes pro-social actions.

In a nutshell, the paper contributes to filling the gap in the community involvement of courts, which is an underexamined area of social responsibility theory. The main aim of the article is to develop a framework of the community involvement of courts based on the theory of social responsibility. The model subordinates the strategy of the court's action to the stakeholders of the organization. In particular, the presented research aims to address the following interconnected research questions:

$R Q 1$. Do courts have the potential for community involvement?

$R Q 2$. Who are the stakeholders that can engage in the pro-social activities of courts?

$R Q 3$. What are the goals of courts' stakeholders?

RQ4. What are the benefits of community involvement for courts? Does community involvement increase the accountability and legitimacy of courts?

RQ5. How can the community involvement of courts be supported and enhanced?

Scientific research on the idea of the community involvement of courts is currently at the grassroots level. Although it has been suggested by practitioners, its implementation and outcomes have been poorly recognized so far also due to the fact of the limited number of courts taking such actions. For this reason, we were first and foremost interested in examining whether and how it is possible to introduce the community involvement of a court into its actions. Taking into consideration the above considerations, we intend to fill the research gap that relates to the applicability of the concept of community involvement into the context of the justice system. An action research method was applied to achieve these 
goals. Using the organization as a "physical laboratory", AR enables the development and testing of practical interventions and allows the advancement of scientific knowledge (Soranzo et al., 2017). The experiences of a Polish regional court served as a source of empirical data. The paper begins with the derivation of the concept of community involvement of courts. Subsequently, the rationale for adopting an action research design is introduced and the institution which is the object of the case study is described. Finally, we go on to present the main results and discuss them from a theoretical and managerial point of view.

\section{Theoretical background of courts' community involvement}

In the business setting, the aspects of responsibility take the form of corporate social responsibility (CSR), which is a concept that adopts the expectations and demands of a wide range of stakeholders, including society, the environment, and individuals, as a factor that determines corporate performance (Yuan et al., 2018). Interest in social responsibility has been extended to the public sector (De Sá Medeiros, 2021). As Cooper (1998) claims, "responsibility is the key concept in developing an ethic for the administrative role" (p. 58). Since the 1970s traditional emphasis on efficiency in the field of public administration has been challenged by scholars and practitioners who emphasize the need for "social justice, moral reasoning, greater collaboration between administrators and citizens, and a more critical analysis of the role of the administrative state in society" (Plant, 2018). We claim that the responsibility of public organizations should manifest in the ethical and transparent management of relationships with key stakeholders of the institution (Gaete, 2008).

Corporate community involvement $(\mathrm{CCl})$ is one of the key components of CSR which is often used to address stakeholders. It relates to interactions between a company and its immediate environment and contributions which an organization voluntarily makes to its community, usually through partnerships with other organizations and taking pro-social actions. According to $\mathrm{CCl}$, organizations serve the community that represents a diverse group of stakeholders who live and exist within a wide coverage boundary (Denni and Cadeaux, 2014). Similar to CSR, CCI usually refers to business organizations. There is a gap in both theory and research that relate to public organizations. To provide a theoretical background for the community involvement of courts, we relate it to institutional theory, stakeholder theory, legitimacy theory and accountability theory (Fusco and Ricci, 2019).

First, changes in the approach of courts toward community involvement are rooted in institutional theory, which suggests that organizations are strongly affected by the institutional environment, such as norms, rules and an understanding of what is acceptable or normal behavior and which cannot be changed easily and/or instantaneously. Institutional theory links responsibility practices to the values and norms of the society in which an organization operates. It argues that organizations apply rules and norms because they seem obvious or natural (March and Olsen, 1983). Failure to act in accordance with norms and expectations may lead to illegitimacy, which is why organizations decide to be isomorphic to other successful organizations. Isomorphic pressures produce increasing similarity among organizations over time (DiMaggio and Powell, 1983). The transfer of ideas is a process that requires adaptation ideas for organizational fields and the translation of the idea by individual organizations to make a concept meaningful (Weiss, 2020). Institutional and later neo-institutional theory has also been applied to the field of public management (Whitford et al., 2020). As we can observe that an increasing number of companies are voluntarily implementing social issues in their operations (Brower and Dacin, 2020), we can expect that such actions may also become a prevailing trend in the public sector (Guthrie et al., 2010), including in courts.

Second, the community involvement of courts is embedded in stakeholder theory. Stakeholders are defined as "any group or individual who can affect or is affected by the achievement of the organization's objectives" (Freeman, 1984). These individuals or groups 
act as arbiters of public value, whose different perceptions of what constitutes public value are relevant (Best et al., 2019). The public value paradigm emphasizes an open-minded relational approach, which also means including less powerful stakeholders such as the local community in collaboration. This is also the idea of the shared responsibility paradigm, which seems to be associated with a duty to behave according to certain principles or goals that are of value, along with other agents (citizens, organizations, institutions), and/or to pursue the achievement of some common goals or states of affairs (Sacconi, 2011). Also, importantly in the context of the issue at hand, stakeholder engagement assumes that an individual or group from outside the organization has a need for information (Greco et al., 2015). After analyzing the expectations and influence of stakeholders, public managers need to develop strategies to manage relationships with stakeholders to increase their support while minimizing their negative impacts on planned decisions. This is of particular importance in crisis situations (Van der Wal, 2020) when the reputation of the courts may be under threat. Therefore, court presidents and managers can use the expectations of stakeholders as the basis for communication to decrease the distance between the institution and its stakeholders to achieve legitimacy.

The concept of legitimacy can contribute to understanding the impact of institutional pressures. Business legitimacy describes the complex relationship between organizations and their environment (Gestel et al., 2020). In his seminal work, Suchman (1995, p. 574) claims that legitimacy may be defined as "generalized perception or assumption that the actions of an entity are desirable, proper, or appropriate within some socially constructed system of norms, values, beliefs and definitions". This approach to legitimacy has its roots in institutional theory and includes such aspects as cognitive, moral and pragmatic legitimacy (Rendtorff, 2020). More recently, Rendtorff (2019) proposed defining legitimacy with reference to corporate social responsibility, corporate citizenship and corporate governance. In this context, legitimacy can be defined as the self-reflective deliberation of an organization on values and ethics (Rendtorff, 2020, p. 22). When a disparity, actual or potential, exists between the two value systems, there is a threat to the entity's legitimacy. Legitimacy is based on the notion that the legitimate organization supports the interests of its stakeholders and is therefore accepted by them. In a governance or regulatory context, power (including regulatory) relations are legitimate where those engaged in them perceive or believe them to be so. Legitimacy lies in the values, interests, expectations, and cognitive frames of those who are perceiving or accepting the regime as they do in the regime itself (Black, 2008). For legal institutions such as courts, legitimacy provides authority, which is essential to judicial effectiveness (Suchanek, 2020, p. 47). Even if people may believe specific decisions are wrong, they still continue to support the court if they respect it as a competent institution, i.e. the court power is still accepted and obeyed by individuals (Gibson and Caldeira, 1995; Wempe, 2009).

To maintain legitimacy, organizations must provide accounts of their activities. Accountability includes a set of standards of conduct for good governance, including the willingness to act in a transparent, fair, compliant and equitable way. It involves the provision of information by an actor or organization, the discussion of or deliberation on that information, and the (potential) imposition of rewards or sanctions in cases of misconduct (Schmidt and Wood, 2019). Accountability means calling an organization "to account" for their actions and having the power to levy sanctions for infringements or malpractices. This model is based on the idea of a two-way relationship between an actor and a forum (the stakeholders) (Greco et al., 2015). Compared to the private sector, expectations pertaining to and obligations toward the accountability of public institutions have always been higher. The new public management reforms resulted in a demonstration of their financial and non-financial performance (Lægreid, 2014). Interest in the subject of accountability is also visible in the practice of court operations (International Commission of Jurists, 2016; Menzies and Melis, 2012). Here we would like to make a distinction between "accountability" of judicial decision-making and "accountability" of the judicial administration. The first is directed toward the individual judge, developing a personal and professional imperative to actually "do the right thing". The second is directed to 
the institutional reputation for integrity, ensuring "that justice should not only be done, but should manifestly and undoubtedly be seen to be done." This external aspect of accountability involves public perceptions (McIntyre, 2019). Although we do not question the independence of judges and courts, we stress the need for stakeholder trust in courts and their belief that activities undertaken in the institutions of the justice system are oriented toward the achievement of social value.

Referring the above considerations to the specificity of courts' activities, we claim that courts, as with private and other public organizations, need to take their stakeholders into consideration, and act in a way that includes publicly accepted norms and values, which also relates to being fair and transparent. In particular, we propose that a court's community involvement refers to voluntarily undertaking long-term actions for the benefit of its stakeholders. Moreover, the court should initiate a number of activities integrating the local environment in which it operates. It becomes a partner, coordinator and initiator of various initiatives for the benefit of society and its own employees. A court that is involved in its community makes efforts to understand and involve stakeholders in its actions and decision-making process. It also communicates undertaken actions clearly to all interested groups and thus becomes transparent. A result of active involvement of the court in prosocial activities, e.g. legal education which stimulates and raises awareness of the significance of problems in the local community, should positively affect its image and increase its accountability and legitimacy, making it a modern and open organization.

\section{Research design and methodology}

The general expectation of our study is to develop the concept of community involvement of courts and test its applicability in court operations. Aligned with the presented research questions, which were expected to generate academic knowledge, the research aimed to foster the application of the idea of community involvement, in line with 'mode 2' research (Harvey et al., 2002) on courts' actions. An action research (AR) approach is particularly suitable for the understanding, planning and implementation of changes in communities, groups or organizations (Coghlan and Brannick, 2014). Additionally, this method is aimed at identifying and solving a specific problem of the organization (Guerci et al., 2018).

This method was also used due to the fact that AR assumes collaboration between researchers, practitioners and laymen (Burns, 2000). Subjects participating in the research and their knowledge are as important as the researcher's knowledge itself in this research. For this reason, the subjects served as a source of knowledge about the problems occurring in the organization which are related to the subject of the study. Additionally, the principal researcher was the president of the court which participated in the research and had deep, valuable prior knowledge of both the organization and stakeholders. The other researchers supported him in the area of theory and data analysis.

Relating to the checklist for action research proposed by Altrichter et al. (2002), the situation described in this article met the following criteria: people developed their work by interlinking their reflections and actions and shared their experiences with other participants and the wider public; participants gathered data in relation to their own questions themselves; participation involved decision-making and power sharing; and the engaged parties could experience the self-reflection process and learning by doing.

Common courts in Poland are attached in terms of administrative issues to the Ministry of Justice. There are the following types of common courts:

- District courts- courts of first instance, which handle most cases;

- Regional court- courts of first and second instance, which handle serious cases and appeals; their jurisdiction covers an area of several district courts; and 
- Appellate courts - courts of second instance, whose jurisdiction covers a territory of at least two regional courts.

The object of this study, the District Court in Gdańsk, is one of the largest courts in Poland (with 153 judges and three referendaries, over 300 administrative employees and 82 side judges). It was selected through purposive sampling due to the court's enthusiasm for the study and the willingness to implement the idea of community involvement. The study was conducted from June 2013 to October 2018. The data collection procedure was subordinated to the requirements of triangulation of sources and respondents. As part of the conducted research, successive observations of the phenomena taking place within the organization were carried out, as were a number of interviews with the court's management, various groups of stakeholders, and quantitative surveys with stakeholders on the subject of collaboration with the court and the quality of this cooperation. Discussions with external experts as well as internal and external stakeholders on the acceptance of the changes introduced, their effectiveness and impact on the perception of the organization were also conducted in the research process.

We started by identifying the problem which was developing the framework for the community involvement of courts. Subsequently, we conducted the research using an approach proposed by Susman and Evered (1978); yet in our case the research was divided into two intervention phases. In each phase we took the following procedure: formulating alternative courses of action for solving a problem (action planning); selecting a course of action (action taking); studying the consequences of actions (action evaluating); and dentifying general findings (specifying learning). The first one familiarized the participants with the idea of court's community involvement, including cooperation with different groups of stakeholders. The change was then planned. Subsequently, activities were undertaken while the process and consequences of the change were analyzed. At the end of the first stage, reflections on these processes took place and the consequences of the implemented activities were determined. At that point, further activities were again planned and implemented, after which the consequences of their implementation were analyzed. This stage was also summarized by means of conclusions and reflections (Kemmis and McTaggart, 2005).

\section{The community involvement of courts: data collection and analysis of the results First stage of the intervention. June 2013 to October 2014}

Action planning. To determine the intervention on the "as is" community involvement, we adopted the approach proposed by Stringer (1996), suggesting that, in an action research project, the changes to a situation should be defined in detail. It was assumed that this stage would enable participants to recognize the potential of implementing pro-social activities in court activities and identify and hierarchize court stakeholders, both in the area of basic court activities and pro-social activities. As a particularly important role in legitimacy processes is played by the image of an organization created on the basis of multilateral communication processes with stakeholders, a means of informing them about pro-social activities which they have undertaken was introduced via the court's website.

Action taking. In this phase, the focus was put on understanding the expectations of external stakeholders. To accomplish this goal, in the period between October 2013 and May 2014, a number of discussions were held with their representatives on the topic of their expectations toward regional court in Gdańsk. Subsequently, in the period from September to October 2014, the court in Gdańsk organized a series of six debates in the form of workshops devoted to the relationship between courts and the social and institutional environment. Participants in these debates included: representatives of the media, legal corporations (prosecutors, advocates, counsels, notaries, etc.), entities supporting the judiciary (experts, mediators, police, the prison service, etc.), and representatives of higher 
education institutions, junior high schools and upper secondary schools. The decision was made to intensify the activities aimed at the integration of mediation partners and to expand international cooperation. Therefore, actions were taken toward organizing a four-day international conference (October 2013) entitled "Mediation as an institution supporting the justice system", in which invited guests from Croatia, Finland, Lithuania and Serbia participated. The practice of permanent (once or twice per week) meetings of the group of court leaders was initiated, the aim of which was to discuss current problems and take prosocial initiatives.

Action evaluating. The outcomes of the implementation phase were assessed. This was done with the parties involved in the previous phase, discussing and analyzing the events of the previous stage. Certain conclusions were drawn as a result. First, the conference allowed participants to meet many foreign and domestic partners and begin the process of building trust between courts and stakeholders. Second, an understanding of stakeholders' needs was launched. As a result, a preliminary stakeholder analysis was conducted. Due to limited space, we will present only the developed stakeholder analysis (Table 2).

Specifying learning. As a result of the activities carried out, it was possible to answer the first two research questions.

\section{$R Q 1:$ Do courts have the potential for community involvement?}

A number of discussions with representatives of other judicial units took place to answer this question. It turned out that courts do not generally undertake pro-social activities, or undertake them incidentally for reasons such as:

- lack of legitimacy for such actions to be taken by courts;

- lack of financial and human resources to carry out activities outside the scope of judicial activity;

- lack of willingness and clearly visible benefits from undertaking pro-social activities; and

- the belief of some judges and court presidents that pro-social activities are a waste of time and energy.

Despite these challenges, the conclusion that stemmed from the discussions was that the potential for community involvement exists. In many cases, if not the courts themselves, it was the judges or presidents of these courts who actively participated in the tasks performed, assumed responsibility for the coordination of some preparatory stages or conducted them on their own. They searched for partners for cooperation and agreed on its details (such activities may include debates or mediator's lounges).

\section{RQ2: Who are the stakeholders that can engage in the pro-social activities of courts?}

Attempts were also made to identify stakeholders that may participate in and support the community involvement actions of courts (Table 1). This list was preceded by a discussion among the court's management, external experts, as well as stakeholders themselves. More detailed analysis was conducted after the second stage of research and is presented later in the text.

\section{Second stage of the intervention. October 2014 to October 2018}

Action planning. From the literature review and discussion among the researchers and the managers involved in the first stage, the implementation of the community involvement of courts was redeveloped. We focused on answering the questions such as "what" activities 
Table 1 Stakeholders in relation to pro-social activities

Internal stakeholders

Court President

Court Manager

Judges and referees

Assistants

Administrative staff

Labor Unions
External stakeholders

Clients

Justice entities (such as police, prosecutors' offices, prison officers) Authorities

Citizens, local communities

Society

Media

need to be taken, "why" it is needed, "who" should be involved, "when" it is most appropriate to conduct it and "how" to do it. The practice of regular meetings among the court's management has been implemented, the purpose of which was to discuss current problems and the division of tasks, in the scope of undertaken pro-social initiatives, among others.

The management practices "Court in the social environment" and "Improving the image of the court" were developed by external experts and the president of the court. To implement the practices, project teams consisting of court employees were appointed. External experts trained the employees and developed a schedule of project teams' activities.

Action taking. In this stage, the next actions aimed at implementing the community engagement of courts were taken. As a result of consultations and discussions between the management of the court and external experts, but also as a result of debates with various stakeholders, the idea to establish so-called advisory and consultative entities that would be an emanation of the idea of participation and collaboration arose. As a consequence, in November 2014, the following entities were established:

- The Chapter of Legal Circles - a platform for the exchange of knowledge and experience between legal corporations and representatives of the world of science (Faculty of Law and Administration of the University of Gdańsk) was created to serve as a forum for training initiatives and exchange of ideas.

- Program Council - in each District Court, a coordinator was appointed to contact school representatives and make initial arrangements. Based on shared experiences, framework guidelines for cooperation between schools and courts were developed, as well as a list of interesting issues that could and should be considered when meeting with young people. Open days organized by the council were attended by 2,800 students from 40 educational institutions.

- Consultative Council - its purpose was to prepare issues for discussion between representatives of various institutions with which the court cooperates as part of its core activities. The Council itself consisted of representatives of various organizations: mediators, District Prison Service, experts, police, the customs service and social welfare centers. Several meetings of the council were held, yet in January 2016, further Council meetings were abandoned as some of the stakeholders who formed the Council functioned within other structures operating at the regional court.

In 2014-2015, a concentration of activities related to improving the qualifications of court officials took place in the District Court in Gdańsk. The pro-social activities of the court would not have been possible without internal stakeholders involved in their organization. The District Court in Gdańsk was also the initiator or co-organizer of interdisciplinary conferences, seminars and debates involving the academic community, social judges, jurors, the local community and prisoners.

Action evaluating. Finally, researchers, managers and external stakeholders involved in the implementation phase discussed the results of the undertaken actions in detail. The impact 
of the implemented management practices on the changes taking place in the judicial organization was assessed. Moreover, a questionnaire survey was conducted among the court's stakeholders to assess the pro-social activities of the District Court in Gdańsk. The results and summary of the second stage of the research led to re-evaluation of the impact and influence of individual stakeholders on the court's pro-social activities and a deeper understanding of their interests. It has also become possible to assess the benefits community involvement and indicate the steps to be taken to build and strengthen social responsibility.

Specifying learning. The answers to further research questions were formulated.

\section{RQ3: What is the significance and what are the goals of stakeholders that can engage in the pro-social activities of courts?}

The next step was to assess the level of significance of the internal and external stakeholders in relation to the abovementioned benefits, which we understand as a level of interest in these goals. The following levels of stakeholder significance were employed:

- high $(\mathrm{H})$ - stakeholders have knowledge of specific issues within the area of strategic objectives of community involvement, and this knowledge influences their actions and is within the scope of their responsibilities;

- medium (M) - stakeholders can benefit from the knowledge gained and its level can influence their position in the organization and the quality of their duties; and

- low $(L)$ - stakeholders of whom the court is independent; the knowledge which they acquire does not directly influence the functioning of the organization, nor does it affect the quality of its activities in various areas.

The results of this analysis are presented in the Table 2. Internal stakeholders who are most aware of the importance of community involvement issues include court presidents, court directors and court decision-makers. External stakeholders, in turn, include those in the judicial area and the media.

\section{RQ4: What are the benefits of community involvement for courts?}

The following benefits of community involvement for courts were identified as a result of the study:

- gaining knowledge pertaining to long-term tendencies in the behavior of stakeholders and understanding their needs related to the administration of justice, which should be characterized by urgency and loyalty toward parties to the proceedings;

- collaboration with stakeholders toward shaping the culture of compliance with, and understanding of, the law in the local community;

- collaboration as part of a partnership with stakeholders for shaping the culture of case settlement;

- establishing relationships that are key to ensuring the stability of employment of internal stakeholders;

- strengthening the accountability and legitimacy of the court;

- improving relations with the public; and

- embedding partnerships in the local community. 


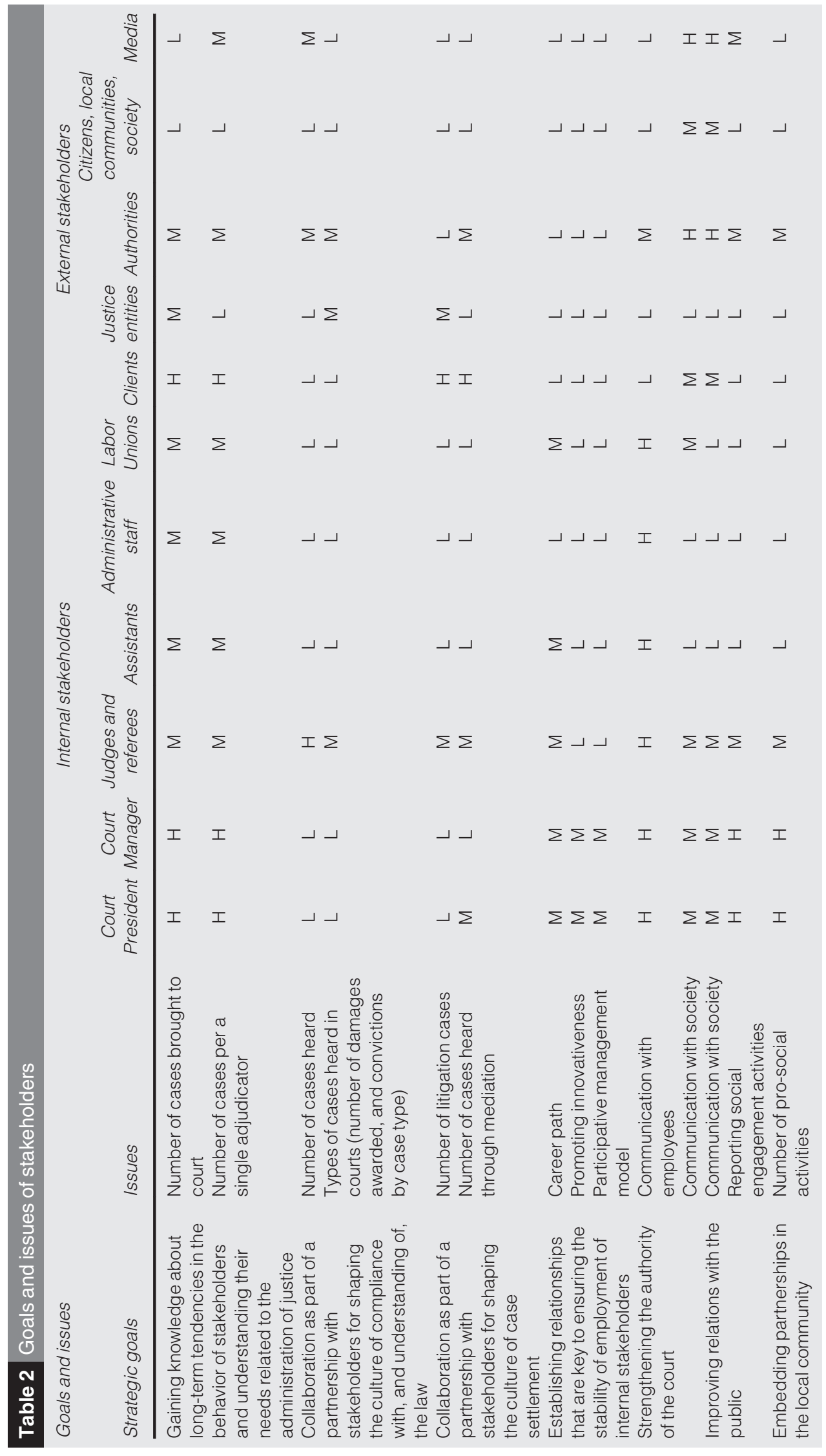




\section{RQ5: How can the community involvement of courts be implemented and supported?}

As a result of the undertaken research process, it was also possible to define the following sequence of steps of the community involvements of public organizations when it comes to courts (Figure 1). At the initial stage, it is first necessary to realize the necessity of undertaking community involvement activities and to identify stakeholders and their needs. During the transitional (second) stage, pro-social activities and their effects should be planned, activities should be undertaken and reported to stakeholders. At the final stage, the established relationships with stakeholders should generate a mutual understanding of social needs. The pro-social activity of the court would increase the legal awareness of stakeholders, which should result in gaining accountability and legitimacy of the court. We posit, that taking these actions finally results in gaining jurisprudence benefits.

\section{Discussion}

In this article, we examine the potential of court engagement in pro-social actions, describe stakeholders and their expectations, explain the basics and the advantages for the court and discover how the community involvement of courts can be enhanced. Relating to the non-jurisprudence values of courts, the presented action research contributes to the discussion of community involvement (Lyra et al., 2017) in the context of the justice system. It shows the usefulness of specific solutions that may enable the courts to become organizations which are capable of integrating stakeholders in a local environment for their common good. Possible new areas of court actions were found and discussed; mechanisms were launched to undertake them efficiently; stakeholders were identified; hierarchies were made in terms of areas of pro-social activities; and the process of making the organization aware of the need to integrate such activities into its current, sustainable functioning was carried out. In addition to contributing to the theory, the use of

\section{Figure 1 A framework for the community involvement of courts}

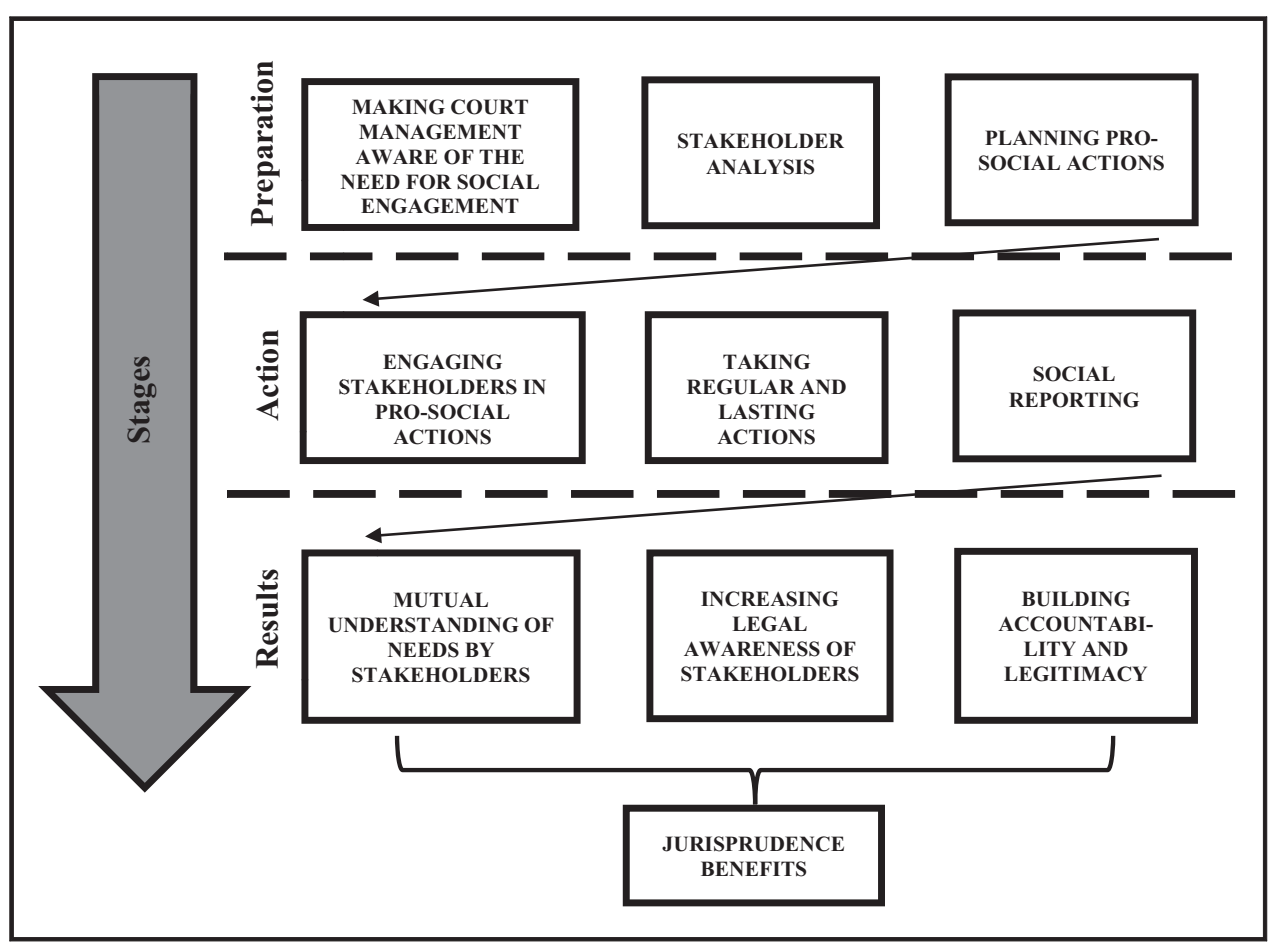

VOL. 18 NO. 62022 SOCIAL RESPONSIBILITY JOURNAL $\mid$ PAGE 1219 
action research resulted in the durability of community involvement which became an organizational routine.

\section{Theoretical implications}

The literature review conducted for this investigation revealed that this study is one of the first studies to investigate the issue of community involvement of courts. Our research contributes to the theory of social responsibility of organizations through the discussion on the applicability of the CSR concept in the public management area, which is a scarce topic (De Sá Medeiros, 2021). We presented the framework of community involvement of courts which is embedded in the theories of community involvement, legitimacy, accountability, stakeholder and institutionalization theory. The framework emphasizes recognition of the stakeholder perspective and building their engagement through dialogue, which includes reporting, thereby contributing to the previous research (Greco et al., 2015; Fusco and Ricci, 2019).

Adopting a stakeholder perspective and community involvement of the public institutions, our research adds to the scarce discussion on qualitative aspects of court performance which are the results of such actions. As a result of the process undertaken, the court has become a source of new values which are also important for stakeholders. Our action research provides support for studies conducted by Wood (2015) who argues that developing legitimacy through interaction with external stakeholders is critical to agency authority. It is also consistent with previous research by Godenhjelm and Johanson (2018), who claim that strong relationships between an organization and its stakeholders are a source of organizational value creation and can result in new and innovative ideas. Presented research shows the usefulness of specific solutions that may enable the courts to become organizations which are capable of integrating stakeholders in a local environment for their common good, and finally increase jurisprudence benefits such as increasing public awareness of the topic of law, which can contribute to a better understanding of the functioning of the court, as well as to the elimination of unfounded appeals against court judgments, and thus reduce the time taken to consider a case. In result, we formulate a conclusion that being oriented toward the needs of stakeholders will allow them to increase the quality of stakeholder relationships and obtain acceptance of their operations (Aljarah et al., 2018), which in turn should increase the effectiveness of the courts.

We identified two critical issues in enhancing the court's community involvement, the first of which relates to the participation of other institutions or entities in the actions undertaken. It turned out that interactions with court stakeholders cannot be perceived solely as a way to respond to the expectations of the local community, but also as a kind of energy exchange resulting from the emerging collaborative synergy. The second one relates to the idea of disclosure which is an act of making relevant information available to provide a transparent image of an organization and enlighten its various stakeholders is required (Garcia et al., 2020).

\section{Managerial implications}

The implementation of the idea of social responsibility will require courts' managers to change the way they operate and subordinate the courts to the influences of the institutional environment, i.e. stakeholders and social forces creating norms, standards and expectations. This means that court administrators should strive to duplicate, and partly modify, standards and good practices in the field of social responsibility used by business organizations for the purposes of the court. Such behavior may consequently lead to an increased level of isomorphism. Such an approach will be a Copernican revolution in judicial organizations. Currently, court administrators, while reforming courts, attempt to influence their environment to obtain the approval of the stakeholders. If the idea of 
corporate social responsibility is implemented in courts, court executives implement standards and good practices from business.

Implementing the concept of social responsibility needs the engagement of key stakeholders, which requires the creation of trust and transparency (Schnackenberg and Tomlinson, 2014). To achieve them courts may and should undertake informational activities (being active in the media, organizing dissemination activities, shaping legal awareness) and educational activities (integration and activation of entities co-creating the justice system, cooperation with schools in the scope of the organization of apprenticeships in court, legal education for youth, free legal advice provided by law students in court, etc.). We also propose that courts should adopt reports on these aspects. It would stimulate public institutions to focus consistently on achieving desirable social outcomes, which contributes to achieving so-called social accountability (Christie, 2018). We propose that the courts implement a model of reporting which obliges the data to be reported on a timely basis in the form of summary reports at lower tier courts, to the higher tier courts, and then to the supervisory authority. Regardless of the summary report, each court would publish a social report on its website to engage in dialogue with the local community. It would also allow for the exchange of good practices and lead to the unification of court activities in the area of community involvement.

Conducting empirical research, we noticed difficulties in implementing social responsibility in common courts. They are hermetic organizations and distrustful of proven business practices, which results mostly from cultural resistance. The dominant values in courts are oriented mainly toward the legal; hence, they are closer to the Weberian model of organization (De Santis and Emery, 2017). Implementing the idea of community involvement requires additional efforts from court managers, and often does not bring any benefits for the organization in the short term. For this reason, we propose that engaging in pro-social activities must be systematic and systemic. Some activities could be given statutory status, and others could be voluntary and adapted to the nature and needs of the local environment. The problem is that the benefits of community involvement are not visible in the short term. Particularly in the first phase of implementation, it is easy to give up on the pro-social actions undertaken to that point, as they go beyond the obligations imposed on the courts and impose additional responsibilities. Therefore, in our opinion, district courts could play a stimulating and monitoring role in opening regional courts to stakeholders. They could identify good practices and pass them on to other courts in the district, as well as to the Ministry of Justice.

\section{Limitations and directions for future studies}

We are aware of the limitations of the study. First, the opportunity to observe longer-term impacts was limited by the duration of the tenure of the President's court. For this reason, a follow-up study that would examine the results of social actions undertaken should investigate how the implementation of the project affected jurisprudence (e.g. the number of appeals, the number of settled cases), comparing the present performance of courts in Gdańsk with past performance or the performance of courts in districts where such activities are not undertaken. The other limitation refers to the research object. As we declared, this court and its stakeholders were willing to collaborate, which is why the research project brought particular results. Actions undertaken in another context could provide more evidence on the implementation of the idea of community involvement and may contribute to the generalizability of our results. Taking translation mechanisms into account, we are aware of the fact that the practices of community involvement may vary according to the environment and organizational context. Thus, the implementation of community involvement will lead to organizational heterogeneity; yet in the next phase, institutional isomorphism should bring up pressures to homogenize organizational practices (Weiss, 2020). Such a process designates another research area. We also had no 
opportunity to engage the Ministry of Justice, who should be a natural partner in providing support to courts. We suspect that its participation would provide financing for pro-social activities and the popularization of best practices of community involvement in the justice system. The results obtained may also be different across common and continental law respectively. In the former, the judge may adjust the judgments to social needs. Courts in the continental system, through community involvement, can make up for a gap in the establishment of relationships with society.

The implementation of the idea of social responsibility in courts' operations requires establishing two-way communication with stakeholders, and social reporting is an excellent tool for this aim. Research in this area should focus primarily on the analysis of practices and standards in the field of social and environmental accounting in private and public organizations (Global Reporting Initiative, 2005; Global Reporting Initiative, 2006; WBG, 2007; AccountAbility 2008a, 2008b; United Nations Global Compact, 2009), and then on the development of a social reporting model adapted to the specificity of courts.

\section{Summary}

Despite the limitations discussed, we believe that the conducted action research provided concrete, significant results related to the change in the organizational approach to the new area of activity, which has finally become important to the organization, although it still needs to be tested during further cooperation with stakeholders. Although this research was conducted in Poland, it may be used in the context of any court, in both the continental and Anglo-Saxon systems. The proposed framework of community involvement of courts is universal and therefore conclusions are of value on an international scale.

To sum up, through the applied action research, we demonstrated how the idea of community involvement can be introduced in the actions of the courts. In particular, the research brought functional and acceptable examples of solutions to the question of how to increase the role of pro-social initiatives in building the position of the court among its stakeholders. Moreover, the study offered suggestions for managers at various levels of management of the judicial organization regarding the type of planned activities, their systematization, validity and measurable effects for the organization, as well as from the point of view of the stakeholders' needs.

\section{References}

Abdelmotaleb, M. and Saha, S.K. (2018), "Corporate social responsibility, public service motivation and organizational citizenship behavior in the public sector", International Journal of Public Administration, Vol. 42 No. 11.

AccountAbility (2008a), AA1000 AccountAbility Principles Standard, AccountAbility, London.

AccountAbility (2008b), "AA1000 Assurance Standard 2008, AccountAbility, London.

Aljarah, A., Emeagwali, L., Ibrahim, B. and Ababneh, B. (2018), "Does corporate social responsibility really increase customer relationship quality? A meta-analytic review", Social Responsibility Journal, Vol. 16 No. 1, pp. 28-49.

Altrichter, H., Kemmis, S., McTaggart, R. and Zuber- Skeritt, O. (2002), "The concept of action research", The Learning Organization, Vol. 9 No. 3, pp. 125-131.

Ates, Z. and Büttgen, M. (2011), "Corporate social responsibility in the public service sector: towards a sustainability balanced scorecard for local public enterprises", Zeitschrift Für Öffentliche Und Gemeinwirtschaftliche Unternehmen, Vol. 34 No. 3, pp. 346-360, available at: www.jstor.org/stable/ 41318670 (accessed 5 April 2021).

Best, B., Moffett, S. and McAdam, R. (2019), "Stakeholder salience in public sector value co-creation", Public Management Review, Vol. 21 No. 11, pp. 1707-1732. 
Black, J. (2008), "Constructing and contesting legitimacy and accountability in polycentric regulatory regimes", Regulation \& Governance, Vol. 2 No. 2, pp. 137-164.

Brower, J. and Dacin, P.A. (2020), "An institutional theory approach to the evolution of the corporate social performance - corporate financial performance relationship", Journal of Management Studies, Vol. 57 No. 4, pp. 805-836.

Burns, R.B. (2000), Introduction to Research Methods, 4th ed., NSW: Longman, Frenchs Forest.

Christie, N.V. (2018), "A comprehensive accountability framework for public administrators", Public Integrity, Vol. 20 No. 1, pp. 80-92.

Coghlan, D. and Brannick, T. (2014), Doing Action Research in Your Own Organization, Sage, Thousand Oaks, CA.

Contini, F. (2010), "The reflective court: dialogue as key for 'quality work' in the Swedish judiciary", in Langbroek, P. (Ed.), Chapter 7 of the Book Quality Management in Courts and in the Judicial Organisations in 8 Council of Europe Memberstates, Montaigne Centre and CEPEJ, Utrecht, pp. 151-173.

Cooper, T.L. (1998), The Responsible Administrator: An Approach to Ethics for the Administrative Role, 4th ed., Jossey-Bass, San Francisco, CA.

Crowther, D. and Seifi, S. (2020), CSR and Sustainability in the Public Sector, Springer Singapore, Print ISBN: 978-981-15-6365-2, Electronic ISBN: 978-981-15-6366-9.

De Sá Medeiros, H., Arruda, S.H. and Forte, C. (2021), "Rethinking state social responsibility with the creation of shared public value", International Journal of Business Administration, Vol. 12 No. 1.

De Santis, L.G. and Emery, Y. (2017), 'Comparing stakeholders' expectations of 'good justice' in Switzerland: toward a 'Hybrid' judicial culture”, Justice System Journal, Vol. 38 No. 1, pp. 78-111.

Denni, I.A. and Cadeaux, J. (2014), "Drivers of corporate community involvement and challenges in measuring its impact", Social Responsibility Journal, Vol. 10 No. 1, pp. 161-183.

Liu, G., Eng, T.Y. and Ko, W.W. (2012), "Strategic direction of corporate community involvement", Journal of Business Ethics, Vol. 115 No. 3, pp. 469-487, doi: 10.1007/s10551-012-1418-z.

DiMaggio, P.J. and Powell, W.W. (1983), "The iron cage revisited: institutional isomorphism and collective rationality in organizational fields”, American Sociological Review, Vol. 48 No. 2, pp. 147-160.

Freeman, R. (1984), Strategic Management: A Stakeholder Approach, Pitman, Boston.

Fusco, F. and Ricci, P. (2019), "What is the stock of the situation? A bibliometric analysis on social and environmental accounting research in public sector", International Journal of Public Sector Management, Vol. 32 No. 1, pp. 21-41.

Gaete, R.A. (2008), "Aplicaciones de la responsabilidad social a la nueva gestión pública (applications of social responsibility to the new public administration)", Documentos y Aportes en Administración Pública y Gestión Estatal, Vol. 8 No. 11, pp. 35-61.

Garcia, E.A. D R., Carvalho, G.M.D., Boaventura, J.M.G. and Souza Filho, J.M.D. (2020), "Determinants of corporate social performance disclosure: a literature review", Social Responsibility Journal, Vol. 17 No. 4 .

Gestel, N.V., Waldorff, S.B. and Denis, J.L. (2020), "(Mis)taking social responsibility? Implementing welfare state reform by private and non-profit organizations", Public Management Review, Vol. 22 No. 12, pp. 1739-1759.

Gibson, J.L. and Caldeira, G.A. (1995), "The legitimacy of transnational legal institutions: compliance, support, and the European Court of Justice", American Journal of Political Science, Vol. 39 No. 2, pp. 459-489.

Global Reporting Initiative (2005), Sector Supplement for Public Sector Agencies: Pilot Version 1.0, Global Reporting Initiative, Amsterdam.

Global Reporting Initiative (2006), Sustainability Reporting Guidelines, Global Reporting Initiative, Amsterdam.

Godenhjelm, S. and Johanson, J.-E. (2018), "The effect of stakeholder inclusion on public sector project innovation", International Review of Administrative Sciences, Vol. 84 No. 1, pp. 42-62. 
Greco, G., Sciulli, N. and D’Onza, G. (2015), “The influence of stakeholder engagement on sustainability reporting: evidence from Italian local councils”, Public Management Review, Vol. 17 No. 4, pp. 465-488.

Guerci, M., Radaelli, G. and Shani, A.B.R. (2018), "Conducting mode 2 research in HRM: a phase-based framework", Human Resource Management, Vol. 58 No. 1.

Guthrie, J., Ball, A. and Farneti, F. (2010), "Advancing sustainable management of public and not for profit organizations”, Public Management Review, Vol. 12 No. 4, pp. 449-459.

Harvey, J., Pettigrew, A. and Ferlie, E. (2002), "The determinants of research group performance: towards mode 2?", Journal of Management Studies, Vol. 39 No. 6, pp. 747-774.

International Commission of Jurists (2016), "Judicial accountability - a practitioners' guide", available at: www.icj.org/wp-content/uploads/2016/06/Universal-PG-13-Judicial-Accountability-Publications-ReportsPractitioners-Guide-2016-ENG.pdf (accessed 17 June 2020).

Jackson, J., Hough, M., Bradford, B., Pooler, T., Hohl, K. and Kuha, J. (2011), "Trust in Justice: Topline Results from the Round 5 of the European Social Survey”, European Social Survey, ESS Topline Results Series.(1).

Kemmis, S. and McTaggart, R. (2005), "Participatory action research: communicative action and the public sphere", in Denzin, N.K. and Lincoln, Y.S. (Eds), The Handbook of Qualitative Research, 2nd ed., Thousand Oaks, CA: Sage Publications Ltd, pp. 567-605.

Lægreid, P. (2014), "Accountability and new public management", in Bovens, M., Goodin, R.E. and Schillemans, T. (Eds), The Oxford Handbook of Public Accountability, Oxford University Press, pp. 324-338.

Lyra, F.R., Barbosa, M.J., Verdinelli, M.A. and Lana, J. (2017), "Corporate social responsibility: comparing different models", Social Responsibility Journal, Vol. 13 No. 4, pp. 728-742.

McIntyre, J. (2019), The Judicial Function. Fundamental Principles of Contemporary Judging, Springer, pp. 227-248.

Maden, C., Arıkan, E., Telci, E.E. and Kantur, D. (2012), "Linking corporate social responsibility to corporate reputation: a study on understanding behavioral consequences", Procedia - Social and Behavioral Sciences, Vol. 58, pp. 655-664.

March, J.G. and Olsen, J.P. (1983), "The new institutionalism: organizational factors in political life", American Political Science Review, Vol. 78 No. 3, pp. 734-749.

Menzies, N. and Melis, E. (2012), "More room for social accountability in the justice sector?", available at: https://blogs.worldbank.org/governance/more-room-for-social-accountability-in-the-justice-sector (accessed 17 June 2020).

Plant, J.F. (2018), "Responsibility in public administration ethics", Public Integrity, Vol. 20 No. sup1, doi: 10.1080/10999922.2017.1413927.

Rendtorff, J.D. (2019), Philosophy of Management and Sustainability: Rethinking Business Ethics and Social Responsibility in Sustainable Development, Emerald Group Publishing, Bingley.

Rendtorff, J.D. (2020), "The concept of business legitimacy: learnings from Suchman", in Rendtorff, J.D. (Ed.), Handbook of Business Legitimacy, Responsibility, Ethics and Society, Springer, pp. 3-30.

Ricci, P. and Fusco, F. (2016), "Social reporting in the Italian justice system: Milan court experience", Public Integrity, Vol. 18 No. 3, pp. 254-268.

Sacconi, L. (2011), "From individual responsibility to 'shared' social responsibilities: concepts for a new paradigm", Towards a Europe of Shared Social Responsibilities: challenges and Strategies, Council of Europe Publishing, Strasbourg Cedex, pp. 35-81.

Schmidt, V. and Wood, M. (2019), "Conceptualizing throughput legitimacy: procedural mechanisms of accountability, transparency, inclusiveness and openness in EU governance", Public Administration, Vol. 97 No. 4, pp. 727-740

Schnackenberg, A.K. and Tomlinson, E.C. (2014), "Organizational transparency: a new perspective on managing trust in organization-stakeholder relationships", Journal of Management, Vol. 42 No. 7 , pp. 1784-1810.

Seattle Municipal Court (2020), available at: www.seattle.gov/courts/about/community-engagement

Soranzo, B., Nosella, A. and Filippini, R. (2017), "Redesigning patent management process: an action research study", Management Decision, Vol. 55 No. 6.

Stringer, E.T. (1996), Action Research: A Handbook for Practitioners, Sage, Thousand Oaks, CA. 
Suchanek, A. (2020), "The problem of corporate legitimacy", in Rendtorff, J.D. (Ed.), Handbook of Business Legitimacy, Responsibility, Ethics and Society, Springer, pp. 31-52.

Suchman, M.C. (1995), "Managing legitimacy: strategic and institutional approaches", Academy of Management Review, Vol. 20 No. 3, pp. 571-610.

Susman, G.I. and Evered, R.D. (1978), "An assessment of the scientific merits of action research", Administrative Science Quarterly, Vol. 23 No. 4, p. 582.

United Nations Global Compact (2009), Corporate Citizenship in the Word Economy, United Nations, New York, NY.

Van der Wal, Z. (2020), "Being a public manager in times of crisis: the art of managing stakeholders, political masters, and collaborative networks", Public Administration Review, Vol. 80 No. 5, pp. 759-764.

Voigt, S. (2016), "Determinants of judicial efficiency: a survey", European Journal of Law and Economics, Vol. 42 No. 2, pp. 183-208.

Weiss, J. (2020), "Managing performance and strategy: managerial practices in German local governments", Public Performance \& Management Review, Vol. 43 No. 5, pp. 1129-1149.

Wempe, B. (2009), "Extant social contracts and the question of business ethics", Journal of Business Ethics, Vol. 88, pp. 741-750.

Whitford, A.B., Milward, H.B., Galaskiewicz, J. and Kkademian, A.M. (2020), "A place at the table: organization theory and public management", Perspectives on Public Management and Governance, Vol. 3 No. 2, pp. 77-82.

Wood, M. (2015), "Beyond accountability: political legitimacy and delegated water governance in Australia", Public Administration, Vol. 93 No. 4, pp. 1012-1030.

Yuan, Y., Lu, L.Y., Tian, G. and Yu, Y. (2018), "Business strategy and corporate social responsibility", Journal of Business Ethics, Vol. 162 No. 2.

\section{Further reading}

European Commission (2017), The Quality of Public Administration "Toolbox", Publications Office of the European Union, Luxembourg.

\section{Corresponding author}

Agata Austen can be contacted at: agata.austen@ue.katowice.pl

For instructions on how to order reprints of this article, please visit our website: www.emeraldgrouppublishing.com/licensing/reprints.htm

Or contact us for further details: permissions@emeraldinsight.com 